\title{
Development of a comprehensive indoor environment indicator for green building labelling in Taiwan
}

\author{
C.-M. Lai \\ Department of Construction Technology, Leader University, Taiwan
}

\begin{abstract}
This paper presents the methodology for developing a comprehensive indicator for indoor environment assessment. It intends to provide the occupants with the measures of Indoor Environment Quality (IEQ). These indicators were drawn up by a literature review based on the practicability, economic and feasible aspects. The categories we considered included acoustics, vibrations, illumination, thermal comfort, indoor air quality, water quality, greens and electromagnetic fields. The AHP (Analytic Hierarchy Process) method was used to carry out the weighting among the categories and these indicators in the same category respectively. The consistency ratio was also calculated to filter out the null questionnaire. Finally, a comprehensive indicator, $I E I_{(A H P)}$ (Indoor Environment Indicator), composed of the filtered indicators, is proposed to assess the indoor environment in built buildings.
\end{abstract}

Keywords: indoor environment, AHP, green building.

\section{Introduction}

It is a common consensus within the "green building" activities that indoorenvironment issue has to be an essential part of the global sustainability. There is a worldwide trend to develop a system that can provide comprehensive performance-assessments of buildings in different environmental scales: global, local and indoor issue. The government of Taiwan is toward this trend. One of the main areas of an environmental assessment method under development is the impact of the indoor environment on occupants' health.

Chen et al. [1] mentioned that indoor environment is important for people's health and welfare, because up to $90 \%$ of a typical person's time is spent indoors. 
Their productivity is also highly related to the indoor environment. Arthur Rosenfeld, a senior advisor at the U.S. Department of Energy (1998), cited a cost/benefit analysis of high-efficiency filtration in an office building. The costs are $\$ 23$ a person for filters and \$1 a person for energy. The benefits are \$39 a person from a $10 \%$ decrease in respiratory disease; $\$ 70$ a person from a $1 \%$ increase in productivity among the $20 \%$ of workers who are allergic; and $\$ 90$ a person by decreasing the productivity loss from building-related illness from $1 \%$ to $0.75 \%$. Those show a strong relationship between IAQ and productivity, and serious initiatives to improve indoor environment have a tremendous return.

Chiang et al. [2,3] pointed out that occupants in a built-environment (illumination, acoustics, air quality, diet, thermal comfort and social environment) reflect the situation, which surrounds them by their physiological and mental sensations (sight, hearing, smell, taste, touch and mentality). The indoor environment is complex and made up of many factors. It's necessary to take various aspects of those environmental factors into consideration, when dealing with the influence of built-environment on occupants.

\section{Method}

This study describes the method of the indoor environment assessment on existing buildings in Taiwan, and intends to draft indoor-environment preservation indicators from eight categories respectively, including acoustics, vibration, illumination, thermal comfort, indoor air quality (IAQ), water quality, greens and electromagnetic fields (EMF).

\subsection{Structure of the indoor environment assessment}

In the similar manner of risk assessment, presented by references [4, 5], we propose a comprehensive index, indoor environment index $\left(I E I_{(A H P)}\right)$, to evaluate the indoor environment. It is assumed that there is an integrated effect accumulated from every category of physical-environment impact on occupants' health. Therefore, the index $I E I_{(A H P)}$ shown in Equation 1 is based on the summation of $S x$, the evaluated score of the physical-environment category $\mathrm{x}$, multiplied by $W x$, the weighting of the physical-environment category $\mathrm{x}$.

$$
\mathrm{IEI}_{(\mathrm{AHP})}=\sum \mathrm{S}_{\mathrm{x}} \cdot \mathrm{W}_{\mathrm{x}}
$$

In addition, there is not less than one indicator in the physical-environment category. The evaluated score of the $i_{t h}$ indicator in the category $\mathrm{x}, S x i$, is evaluated on a score-grade of 20,40,60, 80 and 100, which corresponded to the risk values on the occupants' health. When the score of Sxi exceeds 60, it means no sanitary risk is incurred. The $S x$ is based on the scores consisted of Sxi. If there exists $S x i<60$, then the score of $S x$ is the minimum of $S x i$ in order to emphasize the worst conditions of indoor environment; if for all Sxi 60, it means that no one is reached sanitary risk, we give $S x$ the arithmetic mean of $S x i$, that's: 


$$
\text { if, } \exists i, S_{x i}<60 \text {, then : } S_{x}=\min \left(S_{x i}\right) \text {, else, } S_{x}=\frac{1}{n} \sum_{i=1}^{n} S_{x i}
$$

\subsection{Weighting}

The analytic hierarchy process (AHP) method, which was developed by Thomas L. Saaty (1971) [6], is carried out to do the weighting, $W x$, among those indicators in the same category respectively. Expertise with respect to every professional field was involved in the process of deciding the relevant weight. To begin with, the literature review, group brainstorming and Delphi method were used for selecting the proposed indicators. These indicators, then, were classified into the independent categories to set up the hierarchy. The nominal-ratio scale of pairwise comparison among the indicators represented as the score from 1 to 9 was adopted, which was filled in a positive reciprocal matrix to calculate the eigenvector and maximum eigenvalue. The consistency ratio was obtained to filter out the null questionnaire when the value of the consistency index (C.I.) was greater than 0.1 . For each category, the weighting value was obtained by the geometric mean of experts' questionnaires.

\subsection{Physical indicators}

According to the literature review and the authors' knowledge, the indoor physical- environment performance and quality was consisted of eight physicalenvironment categories. Each category is then expressed in its relevant indicators for field measurement as illustrated in Table 1. There are 48 items of the total indicators as the precise version, then, due to the consideration of the practicable, economic and acceptable aspects, we select 24 items of those significant indicators for simplifying the assessment process as the practical version. These items and their weightings of the physical categories and indicators are determined by the experts' consultation using the AHP analysis.

\section{Determination of the essential category and the weighting}

From Equation 1, there are two processes of the assessment procedure on the indoor physical-environment. Presented in first process is to determine the essential physical-categories and their relative weighting by the experts' questionnaire. Presented in second process is to define the relationship transferred the physical magnitude of each indicator respectively into the score represented from 20 to 100 .

The original weighting is listed in sequencing: "IAQ" $(0.221)$, "Thermal comfort" (0.159), “Acoustics" (0.155), "Illumination" (0.125), "EMF" (0.103), "Greens" (0.070), "Vibration" (0.054) and "Water quality" (0.051). This occurrence reflects the opinions from the experts on the practical aspects of the recent period and the domestic situation. According to the economic sense, the minor categories whose weighting were less than 0.1 were filtered out. It means that the influence ratio of each minor category is less than $10 \%$ of whole benefit for the recent environment. Figure 2 shows the results after the adjustment, there 
are five categories left, and the adjusted weighting is listed in sequencing: "IAQ" (0.290), “Thermal comfort" (0.208), “Acoustics" (0.203), "Illumination" (0.164) and "EMF" (0.135). Substituting the adjusted weighting into Equation 1, we get:

Table 1: Lists of the indoor physical-environment indicators.

\begin{tabular}{|c|c|c|c|c|c|}
\hline \multirow{2}{*}{$\begin{array}{l}\text { Physical } \\
\text { category }\end{array}$} & \multirow{2}{*}{ Indicators for assessment } & \multicolumn{2}{|c|}{ Precise version } & \multicolumn{2}{|c|}{ Practical version } \\
\hline & & $\begin{array}{c}\text { general } \\
\text { dwelling }\end{array}$ & $\begin{array}{c}\text { office } \\
\text { building }\end{array}$ & $\begin{array}{c}\text { general } \\
\text { dwelling }\end{array}$ & $\begin{array}{c}\text { office } \\
\text { building }\end{array}$ \\
\hline \multirow{11}{*}{ Acoustics } & TNEL $_{30}$ & & & & \\
\hline & TNEL $_{30}$ & & & & \\
\hline & $\begin{array}{l}\text { Equalized sound pressure level in morning time } \\
\qquad\left(\mathrm{L}_{\mathrm{eq}} \mathrm{M}\right)\end{array}$ & & & & \\
\hline & Equalized sound pressure level in daytime $\left(\mathrm{L}_{\mathrm{eq}} \mathrm{D}\right)$ & & & & (2) \\
\hline & $\begin{array}{l}\text { Equalized sound pressure level in night time } \\
\left(\mathrm{L}_{\mathrm{eq}} \mathrm{N}\right)\end{array}$ & & & & \\
\hline & $\begin{array}{l}\text { Equalized sound pressure level in } 24 \text { hours } \\
\left(\mathrm{L}_{\mathrm{eq}} 24 \mathrm{H}\right)\end{array}$ & & & (a) & \\
\hline & $\mathrm{L}_{10}$ & & & & \\
\hline & $\mathrm{L}_{50}$ & & & & \\
\hline & $\mathrm{L}_{90}$ & & & & \\
\hline & NR curve & & & & \\
\hline & NC curve & & & & \\
\hline \multirow{9}{*}{ Illumination } & Average illuminance at the targeted face & & & & \\
\hline & Average artificial illuminance at the targeted face & & & & \\
\hline & $\begin{array}{l}\text { Uniformity ratio of illuminance at the targeted } \\
\text { face }\end{array}$ & & & & \\
\hline & $\begin{array}{c}\text { Uniformity ratio of artificial illuminance at the } \\
\text { targeted face }\end{array}$ & & & & \\
\hline & Ratio of daylight-use & & & & \\
\hline & Direct glare at the window face & & & & \\
\hline & Discomfort glare of lamps & & & & \\
\hline & Color temperature of lamps & & & & \\
\hline & Color rendering index & & & & \\
\hline \multirow{9}{*}{$\begin{array}{l}\text { Thermal } \\
\text { comfort }\end{array}$} & Indoor temperature & & & & \\
\hline & Indoor humidity & & & & \\
\hline & Indoor air velocity & & & & \\
\hline & PMV & & & & \\
\hline & Temperature difference in altitude & & & & \\
\hline & Solar heat gain & & & & \\
\hline & Outdoor temperature & & & & \\
\hline & Outdoor humidity & & & & \\
\hline & Outdoor air velocity & & & & \\
\hline \multirow{14}{*}{$\begin{array}{c}\text { Indoor air } \\
\text { quality }\end{array}$} & Suspended particle, $\mathrm{PM}_{2.5}$ & & & & \\
\hline & Suspended particle, $\mathrm{PM}_{10}$ & & & & \\
\hline & Carbon monoxide $(\mathrm{CO})$ & & & & \\
\hline & Carbon dioxide $\left(\mathrm{CO}_{2}\right)$ & & & & \\
\hline & Formaldehyde $(\mathrm{HCHO})$ & & & & \\
\hline & Volatile organic compounds (VOCs) & & & & \\
\hline & Ozone $\left(\mathrm{O}_{3}\right)$ & & & & \\
\hline & Radon (Rn-222) & & & & \\
\hline & Bacteria & & & & \\
\hline & Fungus & & & & \\
\hline & Endotoxin & & & & \\
\hline & Allergen & & & & \\
\hline & Ventilation rate & & & & \\
\hline & Locally average air age & & & & \\
\hline Water quality & Tap water quality & & & & \\
\hline Greens & Greens covered rate & & & & \\
\hline Vibration & Whole body vibration exposure factor & & & & \\
\hline \multirow{2}{*}{$\begin{array}{l}\text { Electromagne } \\
\text { tic fields }\end{array}$} & ELF electric field intensity & & & & \\
\hline & ELF magnetic flux & & & & \\
\hline
\end{tabular}


Table 2: $\quad$ Scale of the evaluated score corresponded to field-measured value.

\begin{tabular}{|c|c|c|c|c|c|c|}
\hline \multirow{2}{*}{$\begin{array}{l}\text { Advised indicators } \\
\text { Through literature review and experts' consultation }\end{array}$} & \multirow{2}{*}{ Units } & \multicolumn{5}{|c|}{$\begin{array}{c}\text { Evaluated score } \\
\text { corresponded to the field-measured value }\end{array}$} \\
\hline & & 20 & 40 & 60 & 80 & 100 \\
\hline
\end{tabular}

“Acoustics" Category

\begin{tabular}{l|l|l}
\hline For dwellings, Equalized SPL in 24 hours $\left(\mathrm{L}_{\mathrm{eq}} 24 \mathrm{H}\right)$ & $\mathrm{dB}(\mathrm{A})$ & $>55 \geqq \quad>50 \geqq>45 \geqq \quad>40 \geqq$ \\
\hline For offices, Equalized SPL in daytime $\left(\mathrm{L}_{\mathrm{eq}} \mathrm{D}\right)$ & $\mathrm{dB}(\mathrm{A})$ & $>59 \geqq \quad>56 \geqq>53 \geqq \quad>50 \geqq$ \\
\hline
\end{tabular}

"Illumination" category

\begin{tabular}{|c|c|c|c|c|c|}
\hline Average illuminance of the ambiance & $1 \mathrm{x}$ & $<70 \leqq$ & $\begin{array}{c}<150 \\
\leqq\end{array}$ & $\begin{array}{c}<300 \\
\leqq\end{array}$ & $<500 \leqq$ \\
\hline Average illuminance at the operated face in offices & $1 \mathrm{x}$ & $<500 \leqq$ & $\begin{array}{c}<750 \\
\leqq\end{array}$ & $\begin{array}{c}<1000 \\
\leqq\end{array}$ & $<1500 \leqq$ \\
\hline Uniformity ratio of illuminance at the targeted face & $\%$ & $<0.5 \leqq$ & $<0.6 \leqq$ & $<0.7 \leqq$ & $<0.8 \leqq$ \\
\hline Ratio of daylight-use & $\%$ & $<0.5 \leqq$ & $<0.7 \leqq$ & $<1.0 \leqq$ & $<2.0 \leqq$ \\
\hline
\end{tabular}

"Thermal Comfort" category

\begin{tabular}{|c|c|c|c|c|c|}
\hline Indoor temperature, summer season & ${ }^{\circ} \mathrm{C}$ & $\begin{array}{l}>29 \geqq \\
<21 \leqq\end{array}$ & $\begin{array}{l}>28 \geqq \\
<22 \leqq\end{array}$ & $\begin{array}{l}>27 \geqq \\
<23 \leqq\end{array}$ & $\begin{array}{l}>26 \geqq \\
<24 \leqq\end{array}$ \\
\hline Indoor temperature, spring \& autumn season & ${ }^{\circ} \mathrm{C}$ & $\begin{array}{l}>28 \geqq \\
<20 \leqq\end{array}$ & $\begin{array}{l}>27 \geqq \\
<21 \leqq\end{array}$ & $\begin{array}{l}>26 \geqq \\
<22 \leqq\end{array}$ & $\begin{array}{l}>25 \geqq \\
<23 \leqq\end{array}$ \\
\hline Indoor temperature, winter season & ${ }^{\circ} \mathrm{C}$ & $\begin{array}{l}>27 \geqq \\
<19 \leqq\end{array}$ & $\begin{array}{l}>26 \geqq \\
<18 \leqq\end{array}$ & $\begin{array}{l}>25 \geqq \\
<17 \leqq\end{array}$ & $\begin{array}{l}>24 \geqq \\
<16 \leqq\end{array}$ \\
\hline Indoor Relative Humidity & $\%$ & $\begin{array}{l}>90 \geqq \\
<30 \leqq\end{array}$ & $\begin{array}{l}>80 \geqq \\
<35 \leqq\end{array}$ & $\begin{array}{l}>70 \leqq \\
<40 \leqq\end{array}$ & $\begin{array}{l}>60 \geqq \\
<45 \leqq\end{array}$ \\
\hline Indoor air velocity & $\mathrm{m} / \mathrm{sec}$ & $>0.45 \geqq$ & $\begin{array}{c}>0.35 \\
\geqq\end{array}$ & $\begin{array}{c}>0.25 \\
\geqq\end{array}$ & $>0.15 \geqq$ \\
\hline PMV & -- & $\begin{array}{l}>2.0 \geqq \\
<-2.0 \leqq\end{array}$ & $\begin{array}{c}>1.5 \geqq \\
<- \\
1.5 \leqq\end{array}$ & $\begin{array}{c}>1.0 \geqq \\
<- \\
1.0 \leqq\end{array}$ & $\begin{array}{l}>0.5 \geqq \\
<-0.5 \leqq\end{array}$ \\
\hline
\end{tabular}

"Indoor Air Quality" category

\begin{tabular}{|c|c|c|c|c|c|}
\hline Suspended particulate matter $\left(\mathrm{PM}_{10}\right), 24 \mathrm{hr}$ & $\mathrm{mg} / \mathrm{m}^{3}$ & $>350 \geqq$ & $\begin{array}{c}>150 \\
\geqq\end{array}$ & $>50 \geqq$ & $>25 \geqq$ \\
\hline Carbon monoxide (CO), $8 \mathrm{hr}$ & ppm & $>15 \geqq$ & $>9 \geqq$ & $>4.5 \geqq$ & $>2 \geqq$ \\
\hline Carbon dioxide $\left(\mathrm{CO}_{2}\right), 8 \mathrm{hr}$ & ppm & $>2500 \geqq$ & $\begin{array}{l}>1000 \\
\geqq\end{array}$ & $\begin{array}{l}>800 \\
\geqq\end{array}$ & $>600 \geqq$ \\
\hline Formaldehyde (HCHO), $8 \mathrm{hr}$ & $\mathrm{ppb}$ & $>1000 \geqq$ & $\begin{array}{l}>100 \\
\geqq\end{array}$ & $>16 \geqq$ & $>8 \geqq$ \\
\hline Volatile organic compounds (VOCs), $8 \mathrm{hr}$ & $\mathrm{mg} / \mathrm{m}^{3}$ & $>3 \geqq$ & $>0.3 \geqq$ & $>0.1 \geqq$ & $>0.5 \geqq$ \\
\hline
\end{tabular}

"Electromagnetic Fields" category

\begin{tabular}{l|c|ccc}
\hline $\begin{array}{l}\text { Electric field intensity of extremely low frequency } \\
\text { (ELF) }\end{array}$ & $\mathrm{kV} / \mathrm{m}$ & $>25 \geqq$ & $>19 \geqq>12 \geqq>5 \geqq$ \\
\hline Magnetic flux of extremely low frequency (ELF) & $\mu$ tesla & $>1600 \geqq \begin{array}{c}>1100 \\
\geqq\end{array} \quad \begin{array}{c}>600 \\
\geqq\end{array}$ & $>100 \geqq$ \\
\hline
\end{tabular}




$$
\begin{gathered}
I E I_{(\text {AHP })}=0.203 \cdot S_{\text {Acoustics }}+0.164 \cdot S_{\text {Illumination }} \\
+0.208 \cdot S_{\text {ThermalComfort }}+0.290 \cdot S_{\text {IAQ }}+0.135 \cdot S_{E M F}
\end{gathered}
$$

The scale being used to transmit the value of the field-measurement to a grade is the score of $20,40,60,80$ and 100 . Table 2 shows the relationship of the evaluated score corresponded to the field-measurement magnitude. These indicators consisted from the five categories were advised through literature review and experts' consultation on the practicable and essential aspects. The manner of score-evaluation was represented a five-interval scale, divided from the physical magnitude, and used a set of references as the benchmarks for determining the scores of $20,40,60,80$ and 100 . Here, the references corresponded to the score 60 were referred to the criteria of the regulation adopted widely for human-health protection. It means evaluated score of any indicator is less than 60 , respectively.

In "Acoustics" category, two indicators, the equalized sound pressure Leq24H for dwellings and LeqD for offices, were included. In "Illumination" category, four indicators, including the intensity of illuminance for the ambiance and the operated face, uniformity ratio and daylight-use ratio, were used for assessment. In "Thermal Comfort" category, there were six indicators for assessment, including indoor temperature in various season, relative humidity, air velocity and PMV. In "IAQ" category, five common indoor air pollutants were appointed as the characteristic compounds. In "EMF" category, the electricfield intensity and the magnetic flux on the extremely low frequency $(50 / 60 \mathrm{~Hz})$ were used.

\section{Conclusion}

The presented results, announced a set of physical indicators, the weightings of various physical categories and evaluated scales corresponded to the fieldmeasured values, are feasible for the assessment on the built environment to benefit the occupants' health. The experts' opinions, based on the recent situation and the domestic environment, were applied.

The project is now proposed to continue with the field measurement and occupants' questionnaire to make up the assessment system, especially on identifying the weightings and the evaluated scales. Also, for a planned building, the project is proposing to develop the assessment method, which suit to the planned building. The same structure will be used, but the input will be taken the place of the data obtained from the checklists, including the quality assurance system, drawings, and descriptions of a building. From many aspects, it is more difficult to predict future.

\section{Acknowledgement}

The authors would like to thank the National Science Council of the Republic of China for financially supporting this research under Contract No. NSC 89-2621Z-006-019. 


\section{References}

[1] Chen, Q., Yuan, X.X. et al., Detailed Experimental Data of Room Airflow with Displacement Ventilation. Proceedings of 6th International Conference on Air Distribution in Rooms, ROOMVENT '98, Stockholm (Sweden), 1998, Vol. 1, pp. 133-140.

[2] Chiang, C.M. et al., Empirical Study on post-occupancy evaluation of housing indoor air environment in Taiwan. Journal of Housing Studies, 1994, No. 2, Jan. RESEARCH, pp.107-132 (in Chinese).

[3] Chiang, C.M., Chou, P.C. et al., A Study of the Impacts of Outdoor Air and Living Behavior Pattern on Indoor Air Quality - Case Studies of Apartments in Taiwan. Proceedings of Indoor Air '96, Nagoya (Japan), 1996, Vol. 3, pp. 735-740.

[4] Anderson, E. L. and Albert, R. E., Risk Assessment and Indoor Air Quality, Lewis Publishers.

[5] Hult, M., Assessment of Indoor Environment in Existing Buildings. Proceedings of Green Building Challenge '98, Vancouver (Canada), 1998, Vol. 2, pp. 139-146.

[6] Saaty, T.L., Erdener, E., A new approach to performance measurement the analytic hierarchy process. Design Methods and Theories, 1979, Vol. 13, No. 2. 